\title{
Finnish WorldSkills Achievers' Vocational Talent Development and School-to-Work Pathways
}

\author{
Laura Pylväs*1 and Petri Nokelainen ${ }^{2}$ \\ ${ }^{1}$ University of Tampere, Faculty of Education, Akerlundinkatu 5, 33014, Tampere, Finland \\ ${ }^{2}$ Tampere University of Technology, Laboratory of Industrial and Information Management, \\ Korkeakoulunkatu 8, 33720, Tampere, Finland
}

Received: 30.01.2017; Accepted: 25.04.2017; Published: 31.08.2017

\begin{abstract}
This paper examines the perceptions of vocational expertise and school-towork pathways among WorldSkills Competition (WSC) achievers and their co-workers and employers within the Finnish context. At the biennial international WSC, young people (aged 18-to-23 years) from over 60 countries demonstrate their skills in more than 40 trades. Individualized training for this competition is provided through the cooperation of vocational institutions (e.g., expert coaches, team leaders and competition panellists) and industry (e.g., mentors, sponsors, materials, equipment). Semi-structured thematic interviews $(N=51)$ were conducted in 2013 and 2014 with former Finnish WSC medal or diploma winners $(n=18)$ who had since begun their working lives (1-to-15 years of work experience). Their employers $(n=16)$ and colleagues $(n=17)$ were also interviewed. Results showed that in addition to vocation-specific knowledge and skills, problem-solving skills, creativity, social skills and self-regulatory skills were acknowledged as the most significant elements of vocational expertise. The findings also indicated that formal vocational education combined with deliberate practice and training based on expert mentoring improved the long-term career progress and vocational expertise of the WSC achievers.
\end{abstract}

Keywords: VET, Vocational Education and Training, Skilled Worker, EducationWork Relationship, Talent Development, Career Exploration

\footnotetext{
${ }^{*}$ Corresponding author: laura.pylvas@uta.fi
}

ISSN: 2197-8646

http://www.ijrvet.net 


\section{Introduction}

Recent research on VET underline the importance of integrating formal education and workplace learning. This reflects the need for students and teachers to learn how to mediate between the different forms of expertise and the demands of different contexts and how to navigate the boundaries between them (Griffiths \& Guile, 2003; Guile \& Griffiths, 2001; Tuomi-Gröhn, Engeström, \& Young, 2003). In the biennial international WorldSkills Competition (WSC), young people (aged 18-23 years) from over 60 countries demonstrate their vocational competence in more than 40 trades (WSI, 2010). The competitors are selected to participate in the WSC based on their success in their vocational studies and in official national competitions. Before the four-day event is held, all competitors participate in an additional training programme. The individualized competition training is carried out in cooperation between vocational institutions (expert coaches, team leaders and panellists) and industry (e.g., mentors, sponsors, materials, equipment). As the WSC offers alternative perspectives on crossing the boundaries between formal education and the workplace, and it finds itself on the political agenda as a strategy to heighten the status of vocational education and training (VET) (European Council, 2010), it is highly relevant to more closely investigate the impact of skills competitions on participants' learning opportunities, outcomes and motivation.

This paper builds on a large interview study $(n=51)$ with vocational skills competition participants and their co-workers and employers in order to gather their perceptions of vocational expertise and school-to-work pathways. The specific focus is on the former WSC medal and diploma winners' perspectives on the development of vocational excellence. The data includes interviews with Finnish WSC achievers $(n=18)$ who have since entered working life (1-15 years of work experience), and their co-workers $(n=17)$ and employers $(n=16)$ from the same workplace. The fertility of the grounds for this research is based on two facts: Firstly, the former WSC achievers have been evaluated as excellent performers by an external international panel, and secondly, they have participated in a training program in which they received guidance from vocational expert mentors. The main goal of this study is to provide information about the advantages and disadvantages of the WSC training in relation to traditionally implemented VET in the context of Finland. This research focuses on an investigation of the WSC achievers' and their non-competing co-workers' perspectives on the main characteristics they consider important to performing well professionally, their vocational pathways after vocational education, and the most important external conditions that have supported their vocational development. The research questions asked by this study are the following:

(RQ1) How is vocational expertise perceived by the former WorldSkills Competition achievers in relation to their co-workers and employers?

(RQ2) What kinds of school-to-work pathways describe the former WorldSkills Competition achievers in relation to their co-workers? 
(RQ3) What kind of influence has the WorldSkills Competition and training experience had on achievers' vocational development and pathways in relation to vocational education?

\section{Theoretical Framework}

\section{WorldSkills Competition}

In the biennial international WSC, young people (aged 18-23 years) from over 60 countries demonstrate their vocational competence in more than 40 trades (e.g., health care, hairdressing and robotics). The WSC is the largest skills competition in the world, in which young professionals compete for the world championship (WSI, 2010). Each competitor receives a score (from 0-600 points) from a panel of international experts based on his or her performance during the four-day competition. Finland provides an interesting context in which to examine the influence of WSC because skills competitions have been included in the country's strategic planning for international cooperation in VET by the Finnish National Board of Education (2014). The participants are the selected students of vocational upper secondary school. Instead of providing financial or material rewards, participation in international competitions allows vocational institutions to compare the quality and elements of their training to those of other countries and improve the skills and international competences of their students (e.g., through international networking) and teachers (e.g., by designing the tasks for the competitions, assessing the performance of contestants together with experts from other countries, and gaining an international perspective into training and teaching at the highest level) (Finnish National Board of Education, 2014).

The competition training system is coordinated by the non-profit organization SkillsFinland and supported by the Finnish Ministry of Education and Culture and the Finnish National Board of Education. The training is implemented in cooperation with vocational institutions (expert coaches, team leaders and WorldSkills Champion Panellists) and industry (e.g., mentors, sponsors, materials and equipment). The training period is mostly individualized and carried out in vocational institutions and workplaces. Moreover, it also includes collaborative practising (e.g., national team camps) (SkillsFinland, 2017). The content of the training is based on the earlier skills competition tasks that follow the VET requirements of vocational qualifications and specialist qualifications and acknowledge the perceptions of experts from different countries. The training is included with the components related to vocation-specific skills and knowledge as well as psychological and physical preparation to overcome competition-related issues (Saarinen, 2010). The training starts approximately one year before the competition. The competitors are selected to participate in the WSC based on their success in the national (Taitaja) skills competition or through training providers' contacts with vocational institutions or companies (SkillsFinland, 2017). According to the WSC achievers interviewed in this study, the impetus to join the competition often comes from the VET teachers and their impressions of their students' success, motivation and willingness to participate in the WSC. 
Developmental Model of Vocational and Professional Excellence

The developmental model of vocational and professional excellence (DMVE) (Nokelainen, 2016; Pylväs, Nokelainen, \& Roisko, 2015) is developed on the basis of the earlier empirical research on modeling of vocational expertise and excellence (Nokelainen, Stasz \& James, 2013; Nokelainen, 2010; Nokelainen \& Ruohotie, 2009; Nokelainen, Korpelainen, \& Ruohotie, 2009; Korpelainen, Nokelainen, \& Ruohotie, 2009; Ruohotie, Nokelainen, \& Korpelainen, 2008; Tirri \& Nokelainen, 2011; Nokelainen, Tirri, Campbell, \& Walberg, 2007; Nokelainen \& Ruohotie, 2002). The DMVE model is applied in this study to investigate the vocational skills competition participants', their co-workers' and their employers' perceptions of the natural abilities, intrinsic characteristics (self-regulation) and extrinsic conditions that influence the development of vocational expertise. The model presented in the Fugure 1 is comprised of the following components: natural abilities (multiple intelligence theory [MI], Gardner, 1983), intrinsic characteristics (the socio-constructivist approach to self-regulation, Zimmerman, 2000), deliberate practice (Ericsson, 2006) and extrinsic conditions (domain and non-domain factors related to talent development, Bloom, 1985; Lave \& Wenger, 1991; Tuomi-Gröhn et al., 2003).

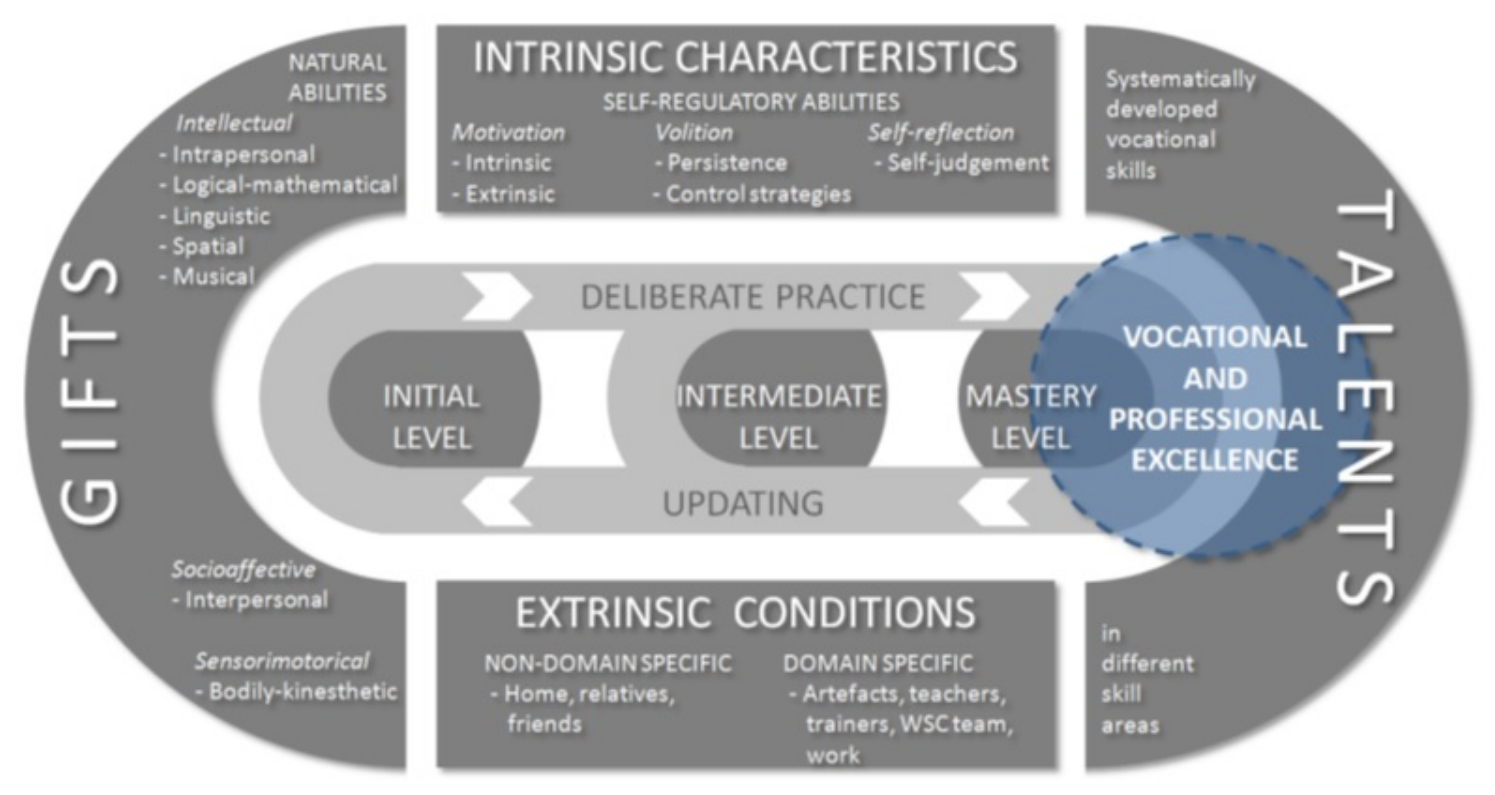

Figure 1: Developmental model of professional and vocational excellence (Nokelainen, 2016; Pylväs et al., 2015)

The model illustrates the process of how inborn gifts develop into talents. Previous research in the domain of vocational skills competitions shows that gifted individuals with exceptional natural abilities (intellectual, creative, socio-affective and sensorimotor), intrinsic characteristics (self-regulation) and auspicious extrinsic conditions (physical, cultural and sociological milieus; exposure to important individuals; activities; accidents) 
may reach a level of vocational excellence through deliberate practice. Individuals who fail to meet all of these conditions may still become competent professionals (vocational expertise) through deliberate practice. (Nokelainen, 2010; Nokelainen, Smith, Rahimi, Stasz, \& James, 2012; Pylväs et al., 2015).

\section{Natural Abilities}

The structure of the main DMVE components (Nokelainen, 2016; Pylväs et al., 2015) is based on Gagné's $(2004,2010)$ differentiated model of giftedness and talent (DMGT). Chance is understood to play a predominant role in the DMGT as it includes both genetic and parental endowments affecting natural abilities and intrapersonal characteristics (Gagné, 2004, 2010). To investigate the role of natural abilities (gifts) in the development of vocational expertise and excellence, DMVE applies the original seven-dimension version of Gardner's (1983, 1993, 1999) multiple intelligence (MI) theory that consists of 1) linguistic; 2) logical-mathematical; 3) musical; 4) spatial; 5) bodily-kinaesthetic; 6) interpersonal; and 7) intrapersonal intelligence. According to Martin (2001), in the workplace learning context, linguistic intelligence refers to an ability to read and produce professional documents and to communicate actively and adaptively with colleagues and clients. Logical-mathematical intelligence is related to technical awareness and an understanding of hardware and software and objective and logical assessments of problems related to people or products. Musical intelligence is related to attendance to auditory cues, such as the tone, volume and sequence of people, machines or environments. Spatial intelligence involves the use of visual elements not only in work tasks and product or service development, but also in other concrete applications related to workplace productivity or marketing. Bodily-kinaesthetic intelligence relates to the motor skills needed to carry out various work tasks, such as an ability to use tools or other equipment efficiently. Interpersonal intelligence is vital in everyday interactions with colleagues and clients, for example, to lead and work within teams and to give constructive feedback. Intrapersonal intelligence refers to a person's self-awareness of one's own feelings, goals, ethics and abilities in changing situations at work.

\section{Intrinsic Characteristics}

Self-regulated learning has been studied in depth mainly in the context of social cognitive theory (Bandura, 1986). The term "self-regulation" refers to the process by which self-generated thoughts, feelings and actions are planned and systematically adapted to further one's learning and motivation (Schunk \& Ertmer, 2000; Zimmerman, 2000). Selfregulatory skills allow learners to modify their performance based on personal characteristics and environmental conditions (Zimmerman, 2000). Further, self-regulated learning is not limited to academic contexts, but can occur wherever learning - whether formal or informal - takes place (Kaplan, 2008). Research has shown that successful learners can monitor and regulate the following triadic elements: volition, motivation and selfreflection (e.g., Kitsantas \& Zimmerman, 2002; Zimmerman, 1989, 1998; Zimmerman \& Kitsantas, 2005). Motivational processes help the learner to formulate decisions and to promote decision-making, whereas volitional processes guide one's subsequent enactment of the decision (Corno, 1989). Volition includes persistence, the will to learn, 
endeavour/effort, mindfulness in learning, regulation, and evaluation processes. It also involves various control strategies (e.g., the allocation and control of resources, emotional attentiveness and motivational control strategies) and methods of processing knowledge (Zimmermann, 2006). The processes of self-reflection enable individuals to evaluate their experiences and thought processes (Bandura, 1986). According to Weiner (1974), individuals constantly seek to understand why an event has occurred. The learner may interpret the failure of a strategy as the result of too little effort (control beliefs) and then decide to increase his or her subsequent effort. The learner may also attribute his or her failure to a lack of ability (efficacy beliefs) when the response will most likely require increasing one's effort. Attribution interpretations (control and efficacy beliefs) can lead to both positive and negative self-reactions because they are under one's own control (Zimmerman, 1998; Zimmerman \& Kitsantas, 1997). Positive reactions reinforce intrinsic goal orientation and positive interpretations of oneself as an employee, such as beliefs in one's own competencies and opportunities (Merenti-Välimäki, Nokelainen, \& Tirri, 2005; Nokelainen et al., 2007).

\section{Deliberate Practice}

Intrapersonal characteristics precede the practice component in the DMGT (Gagné, 2004, 2010) because practice is based on the presence of gifts (natural abilities) and intrapersonal characteristics (e.g., self-regulation). Deliberate practice is essential in talent development; in most fields, it takes ten years to become an expert (Ericsson, Krampe, \& Tesch-Römer, 1993). Recent research, however, has shown that the ten-year rule is not absolute; in some fields (e.g., chess, sports) total mastery of the necessary skills takes about six years, whereas in other fields (e.g., music, science), reaching the top can take 20-30 years of deliberate practice (Ericsson, 2006). Ericsson's relative approach to the study of experts' characteristics assumes that the fundamental capacities and domains - the general reasoning abilities of experts and non-experts alike - are almost identical. The major difference between experts and novices is that through deliberate practice, the former are more knowledgeable than the latter (Chi, 2006). However, to truly understand the influence of the environment on the maximum level of performance, deliberate practice must be characterized and distinguished from other types of everyday activities in which learning may be an indirect result. Ericsson et al. (1993) define deliberate practice as a "highly structured activity, the explicit goal of which is to improve performance" and link deliberate practice to such factors as engagement, motivation and monitored performance.

\section{Extrinsic Conditions}

Environmental conditions also follow intrapersonal characteristics in the DMGT (Gagné, $2004,2010)$ as the differences in "normal" environments fail to explain differences between average and outstanding achievement (Greenspan, Solomon, \& Gardner, 2004). However, environmental conditions have been proven to play an important role in talent development. From a social-cognitive view of self-regulation, expertise develops from both external support and self-directed practice sessions (Bloom, 1985; Zimmerman, 2006). Earlier talent research (Bloom, 1985; Greenspan, Solomon, \& Gardner, 2004) has 
identified three stages of talent development through which talented children progress: initial participation (first attraction to the activity and initiation of formal instruction), perseverance (acquisition of basic and intermediate skills), and mastery (building upon acquired skills to develop expertise and to compete on higher levels). According to Bloom (1985), parents make the talent field accessible and desirable to their children. The home environment provides the structure necessary for early learning (time, valuation, support, resources, and instruction) and instils the child's work ethic. The work ethic applies initially to most activities in the home and school, and later relates most directly to learning and participation in the chosen talent field. The social reactions of parents and other individuals in the immediate environment establish a child's original motivation and engagement in the domain, and when added to the accumulated experience and the help of teachers and coaches, a developing individual learns to internalize methods for assessing improvement, monitoring the effects of practice and setting goals (Bloom, 1985).

In the context of workplaces, the contribution of individual assistance and support by more experienced co-workers also seems to provide a significant basis for learning (Billett, 2001; Virtanen, Tynjälä, \& Eteläpelto, 2014). Without the existence of a theoretical basis for understanding and guidance from experts, student learning at work may remain unsystematic and incidental (Collin \& Tynjälä, 2003; Virtanen \& Tynjälä, 2008). In socio-cultural theories of workplace training, learning is becoming a process situated within the framework of participation rather than within the learner, even if it does not replace notions of individual learning (Hager, 2013). Eraut (2000) argues that aspects of an individual's knowledge accumulated through lifelong learning will always exist and become unique to them. Still, an individual is likely to encounter knowledge that is shared among the group with which he or she works. Lave and Wenger (1991) have proposed that learning happens in everyday interactions and through participation in communities of practice. Learning occurs as part of a process in which learners gradually move from peripheral participation to full participation in the community of practice. However, the master-novice relationship and the professional monopoly on expertise (based on such factors as age or status) may be important elements but are also problematic. Multiple contexts demand and afford different but complementary - yet sometimes conflicting cognitive tools, rules, and patterns of social interaction (Fuller \& Unwin, 2004). The criteria of expert knowledge and skill is defined differently in various contexts; by operating in, and moving between, multiple parallel activity contexts, experts face challenges when negotiating and combining elements from different contexts to achieve hybrid solutions. According to Tuomi-Gröhn et al. (2003), the school should prepare its teachers and students to work as boundary crossers between the worlds of school and work and engage students in real-life processes during their studies as students can see things from a fresh angle, have time to reflect and take the initiative before they are caught up in the routines and dynamics of the workplace. 


\section{Methods}

\section{Participants}

The data includes interviews with Finnish WSC medal or diploma winners $(n=18)$ who have since entered working life (1-15 years of work experience), and their co-workers $(n=17)$ and employers $(n=16)$ from the same workplace. The WSC achievers interviewed participated in the WSC between 1997-2011 and earned either a gold, silver or bronze medal, or a diploma (for being awarded more than 500 points). Going through the WSC high-standard evaluation process, the WSC achievers are being considered to perform on the high level of expertise in this study. To account for the differences between vocational fields, the interviewees were chosen to represent three different trades designated by the researchers: 1) customer service; 2) manual labour; and 3) technical work (Table 1).

Table 1: Overview of the sample

\begin{tabular}{llll}
\hline $\begin{array}{l}\text { Participants } \\
(N=51)\end{array}$ & $\begin{array}{l}\text { WorldSkills achievers } \\
(n=18)\end{array}$ & $\begin{array}{l}\text { Co-workers } \\
(n=17)\end{array}$ & $\begin{array}{l}\text { Employers } \\
(n=16)\end{array}$ \\
\hline Age, $M_{\text {age }}\left(S D_{\text {age }}\right)$ & $29.4(5.012)$ & $32.0(7.433)$ & $46.1(7.191)$ \\
\hline Female $n(\%)$ & $7(13.7)$ & $8(15.7)$ & $7(13.7)$ \\
\hline Male $n(\%)$ & $11(21.6)$ & $9(17.6)$ & $9(17.6)$ \\
\hline Work experience, years $(S D)$ & $8.7(4.081)$ & $12.2(6.978)$ & $24.0(8.556)$ \\
\hline
\end{tabular}

\section{Instrument}

A total of 51 semi-structured thematic interviews (70-90 minutes) were conducted in 2013-2014 in 18 workplaces. Interviews served as the research method offering some leeway to pursue the angles deemed important by the interviewee, while also enabling the interviewer to focus the conversation on issues considered important to the research (Brinkmann, 2014). The interview instrument was developed on the basis of our previous research on vocational expertise and focused on examining the significance of natural abilities, intrinsic characteristics (self-regulation) and extrinsic conditions in the development of vocational expertise (e.g., Pylväs et al., 2015). Questions such as "How would you characterize an employee who succeeds well in your vocation?" or "How do you think that vocational education has prepared you for working life?" were included in the interviews.

\section{Analysis}

We used qualitative content analysis to analyse the research data. Qualitative content analysis can be defined as a research method used for the subjective interpretation of the content of text data through the systematic classification process of coding and identifying themes or patterns (Hsieh \& Shannon, 2005). The aim of the analyses was to create conceptually and empirically grounded categories related to the analytical context and rooted in empirical material to reflect the topic of the study (e.g., Dey, 1993). We obtained the text data from transcribed semi-structured interviews, which we managed 
(by organizing data sources and managing coding) using NVivo software. The unit of analysis selected for coding was a meaningful piece of text in the interview transcript, such as a word, sentence or short narrative (Krippendorff, 2012; Schreier, 2014). The coding frame consisted of the main categories and subcategories built by following the directed (or deductive) analysis approach based on the existing theory (Hsieh \& Shannon, 2005; Schreier, 2014). However, since a key objective was to provide a thorough description of the material, we combined concept-driven categories with data-driven categories (Schreier, 2014). Thematic criteria served to divide the text material into data-driven units that would fit the coding frame (Schreier, 2014). When an important characteristic separates people into groups, one or more groups can also be selected as units of analysis (Patton, 1987). In this study, the sampling units consisted of both coding units (main categories and subcategories) and three demographic groups of interviewees (WSC achievers, co-workers and employees).

\section{Results}

How is vocational expertise perceived by the former WorldSkills Competition achievers in relation to their co-workers and employers?

The WSC achievers and their co-workers and employers shared a similar view of the most important skills related to vocational expertise: logical-mathematical skills, interpersonal skills and self-regulatory skills. The role of intelligences (natural abilities) will first be discussed, followed by a discussion on the role of self-regulatory skills.

Natural abilities. According to the interviewees, vocation-specific skills may not be the most critical of all the vocational skills, but they are required to perform well in vocational fields. Depending on the vocational field, one must have the necessary vocation-specific skills emphasising e.g., sensorimotor skills (bodily-kinaesthetic abilities supporting manual skills) and/or logical-mathematical skills (domain-specific knowledge). All of the interviewed groups highlighted the importance of logical-mathematical skills, but there were also the differences in terms of the cognitive skills that were considered the most important. The WSC achievers and employers underlined the importance of problemsolving skills more than the co-workers did and they believe that sufficient cognitive skills are the foundation for actualizing vocational excellence. These two groups discussed the importance of a broad understanding of the work processes that enable an employee to handle multiple tasks and to overcome various and unexpected problems independently and quickly. Moreover, the employers highlighted the importance of commercial expertise as many vocational trades involve working in private companies.

Creativity was one of the vocational skills highlighted in many of the interviews, particularly by the WSC achievers. Creativity was included with the artistic and visual skills needed in vocations such as florist and hairdresser. On the other hand, creativity was related to the creative thinking that may inspire a person to create something new, such as a new idea or method of working. Thus, creativity was also closely connected to problem-solving skills and innovativeness. To perform at the level of vocational excel- 
lence, a person was considered to need the ability to create, innovate or solve problems independently. "Excellence then requires more logical thinking, to be able to apply everything one has ever seen, heard or done. Such skills and adequate work experience help one to become a top expert" (WSC achiever).

All of the interviewed groups also emphasized the significance of interpersonal skills as an element of vocational expertise. Several aspects of interpersonal skills were brought up in the interviews: the knowledge of human nature, extroverted personality, energetic and positive attitude, open-mindedness and encouragement, flexibility and humility, customer service orientation, teaching skills and mentoring skills. In some cases, interpersonal skills were even seen to compensate for the lack of some other vocational strengths such as manual skills. Only a few of the WSC achievers and their co-workers mentioned spatial skills (three-dimensional skills), linguistic skills (language skills, writing, documentation and guidance) and intrapersonal skills (recognizing one's own strengths and weaknesses) in the context of vocational expertise.

Self-regulation. The interviewees of the three target groups specified multiple characteristics related to self-regulation that they considered important or vital to their vocational expertise and vocational development. Most importantly, the interviewees emphasized the significance of the following self-regulatory skills: volition (concentration, calmness, carefulness and organizational skills) and internal motivation (ambition to learn and develop professionally, initiative). Volition was decribed by an interviewee: "And perseverance and patience is needed in everything, because if there are any problems or other hassles, it takes time to make sense of it. Perseverance is needed, at least" (Co-worker).

The co-workers, in particular, highlighted the importance of internal motivation in the vocational field and work tasks. There were also a few interviewees in each group of interviewees who discussed external motivational factors that may have an influence on one's professional development, such as ambition, expectations of career progression and ongoing changes in the work environment. Overall, motivation was recognized as an important prerequisite for vocational expertise. Self-reflection was acknowledged by all of the target groups even if it was less emphasized than volition and motivation. Tolerating stress in high-pressure work situations and reflecting on one's own performance were both perceived as important in working life.

What kinds of school-to-work pathways describe the former WorldSkills Competition achievers in relation to their co-workers?

To analyse the participants' vocational pathways, the results follow the three identified stages of talent development (Bloom, 1985; Greenspan, Solomon, \& Gardner, 2004) discussing initial participation (first attraction to the vocational field), perseverance (acquisition of basic and intermediate skills in VET), and mastery (building upon acquired skills to develop expertise and to compete on higher levels at work).

Initial interest. The background to the interviewees' initial interest in their vocational fields was largely consistent among both the WSC achievers and their co-workers. The most common statements were related to an interviewee's personal interest in their chosen 
vocational field and their family background: "Maybe it was because I saw my mother working and enjoying it, and I saw how much she got out of it" (Co-worker).

Family and friends were the greatest influences on the choices of profession, thus supporting Bloom's (1985) concept that parents make the talent field accessible and desirable to their children and the home environment provides the structure necessary for early learning. Our data shows that the decisions were guided by such factors as family members' professional backgrounds, the immediate family environment (e.g., available equipment, authentic work experiences) and the family members' confidence in the education system and their children's aptitudes for certain skills areas. A few of the interviewees from both target groups had also found their career path through work experience (e.g., workplace training in secondary school or non-military service) or a vocational school tour. In addition, some of the interviewees had chosen their career based on their study success or education offerings.

I came from a family of farmers, so manual skills have always been there. My uncle developed patents for some agricultural stuff, so it surely comes from there somewhere. In fact, I can see the same thing now in my own two sons; somehow they are more technically oriented (WSC achiever).

Study period. The WSC achievers' and their co-workers' experiences of their study period diverged at some level. Most of the WSC achievers considered themselves more successful than average students. They actively studied not only in a formal setting, but also in their spare time. They also greatly emphasized their internal motivation towards the vocational field and their enthusiasm for vocational education throughout their studies. Some of the WSC achievers described themselves as conscientious and hard-working students and the others underlined how their advanced studying skills helped them to succeed in their studies. Furthermore, some of the interviewed co-workers considered themselves to be more successful in their studies than average students. Among those interviewees, study success was also seen as being based on their conscientious and hardworking characteristics, study habits and strong motivation.

Yes, I was different from others. If I think back on our class, then yes, I certainly was the only one who studied from morning until evening. . Maybe I differed in the sense that I had a strong will to learn. I think that is why I was chosen to participate in this event even though we would have had, as far as I recall, three other candidates to go (WSC achiever).

While only a few of the WSC achievers considered themselves to be average students during their studies, most of the co-workers assessed themselves as having performed at an average level. Their average or lower level of study success was seen as the result of such factors as young age, lack of motivation, lack of earlier work experience or random choices made in their career and training.

Working life. The WSC achievers acknowledged their strong professional networks, easy school-to-work transitions, high levels of expertise and career success more often than 
their co-workers. Half of WSC achievers mentioned that finding a job after graduation was easier because of the contacts they had gained during the skills competitions. The WSC achievers also described their career development in working life as better than average more often than their co-workers. This was supported by more than half of the employers who acknowledged the exceptionally high level of expertise of the interviewed WSC achiever working in their organization: "I could let [the WSC achiever] run the business quite confidently, he is that rock-solid a professional; he knows what to do" (Employer).

The higher level of vocational expertise was included with vocation-specific natural abilities (e.g., technical knowledge, sensori-motor skills) and self-regulatory skills (e.g., motivation, self-confidence, volition, self-reflection and learning skills). A little more than one-third of the employers also considered the WSC achievers working in their organizations to be above average in terms of career development.

For sure, the biggest factor is the contacts. But the fact is that the contacts were earned through my success in vocational competitions. Let's put it this way: if I were to become unemployed for some reason, I would find a new job through these contact networks, and very quickly (WSC achiever).

Some (less than one-third) of the co-workers also described their career development in working life as better than average and believed that the work experience or practical training they gained during their studies had influenced their school-to-work transition. Those co-workers who also felt that they had superior expertise to average employees acknowledged their strong self-regulatory skills.

The WSC achievers' and co-workers' thoughts concerning their work-related future ambitions revealed no particular differences. Both groups discussed the significance of lifelong learning, the ambition to learn and motivation to develop professionally. Career development was related to assuming responsibility for work tasks and further education. The common future interests of the co-workers were related to creating a private enterprise, engaging in further education, working in international environments and projects or be promoted in the organization. The WSC achievers emphasized slightly more often their career development, professional development and teaching/coaching (e.g., vocational skills competitions) ambitions. Moreover, a few of the WSC achievers mentioned the possibility of a career change, two of them for medical reasons.

What kind of influence has the WorldSkills Competition and training experience had on achievers' vocational development and pathways in relation to vocational education?

The study had a specific focus on former WSC achievers' perspectives on the advantages and disadvantages of skills competitions. The empirical finding implied that the WSC achievers acknowledged several benefits of the WSC and training. In particular, they reported gaining a boost in their career due to gaining access to a high level of expertise and extensive professional networks. The WSC supported the WSC achievers' schoolto-work transitions and strengthened their reputations and vocational confidence: "New 
situations will not make you nervous, because you have experienced so much that you know how to handle them" (WSC achiever).

Skills competition experience and training was also considered to develop or strengthen self-regulatory skills such as volition (e.g., perseverance and exactness), motivation in the vocational field and self-reflection (e.g., stress-tolerance and self-confidence), as well as logical-mathematical skills (e.g., technical knowledge and skills, problem-solving skills and special expertise) and interpersonal skills (e.g., collaborative learning and customer service).

Some of the employers also highlighted the advantages of the skills competitions and training, as they had found the WSC achievers to have strong self-regulatory skills (e.g., motivation, volition and determination), logical-mathematical skills (e.g., technical knowledge and skills) and interpersonal skills (e.g., customer service and social skills). However, a few of the WSC achievers perceived no discernible advantage from participating in the skills competition. Some of those interviewees stated that the competition tasks were inconsistent with real working life, while others noted that their success went unacknowledged outside of the competition environment or the training failed to meet expectations.

The group most satisfied with formal VET was the WSC achievers who considered their studies to have been an important basis for their vocational expertise and considered them advantageous later in their career: "I feel that [...] I have gained good skills there [vocational education]. And the thing that I have certainly understood over the years is specifically lifelong learning" (WSC achiever).

Participation in the skills competition and training had even sparked some of the WSC achievers' interest in teaching in vocational institutions or coaching in skills competitions.

Overall, the significance of workplace learning was underlined by all groups of interviewees. Both the WSC achievers and their co-workers believed that an authentic work environment enables a student or novice employee to explore actual work tasks, to learn by doing and to become familiar with the hectic schedules of working life. One of the WSC achievers acknowledged that the WSC and training provides one with the opportunity to devote more time to learning, which one seldom has in the workplace. Those employers who described workplaces as "the main learning environment" felt that formal VET only provides a student with certain basic skills to use in the beginning of their career, based on the assumption that the rest of their knowledge and skills will be acquired on-the-job.

... there should be more work, more hours of work. We did not have that much client work. It would be important to have holistic work tasks, to have a specific time frame in which to manage the whole task, more orientation towards authentic work (WSC achiever).

Some of the WSC achievers, co-workers and employers also expressed their discontent with formal vocational education. The criticism was concerning the outdated knowledge (lack of recent work experience and further education) of teachers, obsolete technology and devices as well as weak or theoretically oriented curriculum. However, some of 
the statements were targeted at certain institutions rather than VET in general. Finally, most of the criticisms of formal vocational education hailed from the employerinterviewees. The employers were especially worried about the lack of commercial expertise (business skills) that was considered important or crucial in any vocational field.

\section{Conclusions}

This study examined the perceptions of former WSC medal and diploma winners, their co-workers and employers regarding vocational expertise and experiences of school-towork pathways. The specific focus of our investigation was to better understand the WSC achievers' perspectives on the influence of vocational skills competitions on their subsequent professional growth processes and career development. The findings showed that the WSC achievers and their co-workers and employers shared a common view of vocational expertise included with both natural abilities and self-regulatory skills. Vocation-specific skills, sensorimotor skills (manual skills) and logical-mathematical skills (contextual knowledge) were seen as the foundation for performing well in a vocational field. All groups emphasized the importance of interpersonal skills; possessing good social skills was even seen as a way to compensate for weakness in some other areas. Self-regulatory skills, volition, motivation and self-reflection, were acknowledged as characteristics that are vital to one's vocational expertise and vocational development. WSC achievers differed from their co-workers by placing a strong emphasis on the importance of logical-mathematical skills (understanding overall work processes, creative thinking and quick and independent problem-solving skills). By contrast, their co-workers dominated in discussions related to the significance of internal motivation.

The results showed some differences between the WSC achievers' and their co-workers' experiences in their school-to-work vocational pathways. Similar factors influenced both the WSC achievers' and their co-workers' choice of career, whether it reflected their personal interest in the vocational field or was based on the recommendation of family members or friends. In a few cases, the decision was based on previous work experience, academic success or the available study opportunities. During their studies, the coworkers' vocational pathways diverged in the sense that most of the WSC achievers, but only a few of the co-workers described their academic success as better than average. Success in their studies was related to strong self-regulatory characteristics, such as internal motivation towards the vocational field and volition (a conscientious and hard-working attitude), coupled with engaging in deliberate practice (individual active studying and advanced studying skills). The significance of workplace learning was underlined more often than formal VET by all the groups of interviewees. Most of the WSC achievers acknowledged the importance of both formal education and WSC to their development of vocational excellence. However, the advantages provided by the WSC and training were also particularly related to crossing the boundaries between student life and working life, thereby providing the student with an opportunity to create extensive professional networks and strengthen their vocational confidence in order to make the school-to-work transition easier and more efficient. 


\section{Limitations}

This study describes the self-reported statements of the three different groups of interviewees with the aim of revealing some interesting findings regarding general factors related to vocational development. To draw further comparative conclusions between the target groups, however, the differences in the participants' backgrounds (e.g., vocational field, vocational school and current employer) create some limitations. Further research focusing on only one specific vocational field might yield more extensive information about vocation-specific career stages and turning points. Futhermore, one of the main factors that determine the success of content analysis and the trustworthiness of the study is a coding process (e.g., Hsieh \& Shannon, 2005; Krippendorff, 2013; Schreier, 2014). Authentic citations have provided examples of meaningful pieces of the text behind the inferences and categorizations and empirical material, as qualitative researchers tend to acknowledge the possibility of multiple interpretations of textual units (Krippendorff, 2013; Patton, 1990). An empirically validated analytical framework served as the basis for the categories. As one of the most critical phases of the content analysis is the requirement of mutual exhaustiveness and exclusiveness (e.g., Schreier, 2013), all relevant aspects of the transcript were intended to cover a category, and any unit of analysis was to be coded only once under one main category to ensure coding consistency.

\section{Discussion}

In this paper, we have discussed the role of natural abilities and intrinsic characteristics (self-regulatory skills) in the development of vocational expertise and excellence. The vocational skills itemized by the interviewees of this study support previous research underlining the significance of both natural abilities (intellectual, creative, socio-affective and sensorimotor) and self-regulatory skills (Nokelainen, 2010; Nokelainen et al., 2012; Pylväs, Nokelainen, \& Roisko, 2015) in vocational achievement. According to Gardner and Moran (2006), multiple intelligences can be related to occupational roles; however, in work contexts, the power of an multiple intelligences (MI) theory can be even greater through an examination of the ways the intelligences interact in individuals or within teams. A variety of potential combinations create different patterns to allow for a wider array of competences and performances to arise as one intelligence can mediate and constrain, compensate or catalyze another. According to the Gardner's and Moran's (2006) approach on interacting intelligences, in this study the WSC achievers underlined the importance of logical-mathematical skills intertwined with creativity. On the other hand, interpersonal skills were considered to compensate for the lack of some other vocational skills. Thus, the findings support the idea that what matters is not only how intelligent a person is, but how varying levels of different intelligences interact within a particular situation or job (Gardner \& Moran, 2006). Further research is needed to better understand the crucial combinations of skills and intelligences needed in changing working life and to go beyond the traditional subject teaching in VET. The same complexity applies to developing vocational expertise in social contexts with multiple people, whether the focus 
of learning is on cognitive, motivational or emotional processes. Collaborative working requires regulative learning skills to co-construct shared task representations, shared goals and shared strategies (Järvelä \& Hadwin, 2013). In working life, the amount of information processing required is usually more than one person can even handle, thereby invalidating the notion of a single, all-purpose intelligence of a single individual (Gardner \& Moran, 2006). In addition to intertwined intelligences, the understanding of shared expertise should also be involved in the pedagogical planning of study assignments to provide opportunities for VET students to develop a sufficient foundation for lifelong learning.

The findings support Bloom's (1985) view on the home environment providing the structure necessary for early learning (e.g., work ethics, motivation and engagement in the domain). Further, in order to control their learning processes independently during their studies and later in their working lives, students were considered to need opportunities to develop strong self-regulatory skills. Following Ericsson's et al. (1993) approach, the empirical results of this study emphasised the importance of deliberate practice to talent (or vocational) development and its connection to such factors as engagement and motivation. Some components of the WSC and training are certainly creating advantageous patterns that ought to be developed further and exploited in VET in general. The time that motivated experts gave to the WSC achievers to practise their vocational skills in authentic environments was perceived as having a positive influence on their motivation in the vocational field, development of vocational excellence, school-to-work transition, and self-confidence. The study of Wilde and James Relly (2015) also found a parallel result; the success of UK participants in the WSC is due to the intense effort, commitment and teaching and learning of the training managers and competitors. This study suggests focusing greater attention on VET students' development of learning skills and self-regulatory skills during vocational education. There is need to provide students with the possibility of strengthening those skills within the sphere of vocational education through the help of teachers but to recognize potential advantages of collaboration with experts from working life. 


\section{References}

Bandura, A. (1986). Social foundations of thought and action: A social cognitive theory. Englewood Cliffs, NJ: Prentice-Hall.

Billett, S. (2001). Learning in the workplace. Strategies for effective practice. Sydney: Allen \& Unwin.

Bloom, B. S. (1985). Generalizations about developing talent in young people. In B. S. Bloom (Ed.), Developing talent in young people (pp. 507-549). New York, NY: Ballantine Books.

Brinkmann, S. (2014). Unstructured and semi-structured interviewing. In P. Leavy (Ed.), The Oxford handbook of qualitative research (pp. 277-299). Oxford: Oxford University Press.

Chi, M. T. (2006). Two approaches to the study of experts' characteristics. In K. A. Ericsson, N. Charness, P. J. Feltovich, \& R. R. Hoffman (Eds.), The Cambridge handbook of expertise and expert performance (pp. 21-30). Cambridge: Cambridge University Press.

Collin, K., \& Tynjälä, P. (2003). Integrating theory and practice? Employees' and students' experiences of learning at work. Journal of Workplace Learning, 15(7/8), 338-344.

Corno, L. (1989). Self-regulated learning: A volitional analysis. In B. Zimmerman \& D. Schunk (Eds.), Self-regulated learning and academic achievement: Theory, research and practice (pp. 111-142). New York, NY: Springer.

Dey, I. (1993). Qualitative data analysis. A user-friendly guide for social scientists. London: Routledge.

Eraut, M. (2000). Non-formal learning and tacit knowledge in professional work. British Journal of Educational Psychology, 70(1), 113-136.

Ericsson, K. A. (2006). The influence of experience and deliberate practice on the development of superior expert performance. In K. A. Ericsson, N. Charness, P. J. Feltovich, \& R. R. Hoffman (Eds.), The Cambridge handbook of expertise and expert performance (pp. 683-703). Cambridge: Cambridge University Press.

Ericsson, K. A., Krampe, R., \& Tesch-Römer, C. (1993). The role of deliberate practice in the acquisition of expert performance. Psychological Review, 100(3), 363-406.

European Council. (2010). The Bruges Communiquè on enhanced European Cooperation in Vocational Education and Training for the period 2011-2020. Retrieved from: http://ec.europa.eu/education/lifelong-learning-policy/doc/vocational/bruges_en.pdf

Fuller, A., \& Unwin, L. (2004). Young people as teachers and learners in the workplace: Challenging the novice-expert dichotomy. International Journal of Training and Development, 8(1), 32-42.

Gagné, F. (2004). Transforming gifts into talents: The DMGT as a developmental theory. High Ability Studies, 15(2), 119-147. 
Gagné, F. (2010). Motivation within the DMGT 2.0 Framework. High Ability Studies, 21(2), 81-99.

Gardner, H. (1983). Frames of mind. New York, NY: Basic Books.

Gardner, H. (1993). Multiple intelligences: The theory in practice. New York, NY: Basic Books.

Gardner, H. (1999). Intelligence reframed: Multiple intelligences for the 21st century. New York, NY: Basic Books.

Gardner, H., \& Moran, S. (2006). At the workplace. In H. Gardner (Ed.), Multiple intelligences: New horizons in theory and practice (pp. 213-232). New York, NY: Basic Books.

Greenspan, D. A., Solomon, B., \& Gardner, H. (2004). The development of talent in different domains. In L. V. Shavinina \& M. Ferrari (Eds.), Beyond knowledge (pp. 119-135). Mahwah, NJ: Lawrence Erlbaum Associates, Inc.

Griffiths, T., \& Guile, D. (2003). A connective model of learning: The implications for work process knowledge. European Educational Research Journal, 2(1), 56-73.

Guile, D., \& Griffiths, T. (2001). Learning through work experience. Journal of Education and Work, 14(1), 113-131.

Hager, P. (2013). Theories of workplace learning. In M. Malloch, L. Cairns, K. Evans, \& B. O'Connor (Eds.), The SAGE handbook of workplace learning (pp. 17-32). London: Sage.

Hsieh, H-F., \& Shannon, S. E. (2005). Three approaches to qualitative content analysis. Qualitative Health Research, 15(9), 1277-1288.

Järvelä, S., \& Hadwin, A. (2013). New frontiers: Regulating learning in CSCL. Educational Psychologist, 48(1), 25-39.

Kaplan, A. (2008). Clarifying metacognition, self-regulation, and self-regulated learning: What's the purpose? Educational Psychology Review, 20, 477-484.

Kitsantas, A., \& Zimmerman, B. J. (2002). Comparing self-regulatory processes among novice, non-expert, and expert volleyball players: A microanalytic study. Journal of Applied Sport Psychology, 14(2), 91-105.

Korpelainen, K., Nokelainen, P., \& Ruohotie, P. (2009). Ammatillisen huippuosaamisen mallintaminen: Huippuosaajaksi kasvaminen ja kasvun edellytykset. [Modeling of Vocational Excellence: Growth conditions of top excellence] Ammattikasvatuksen aikakauskirja [Journal of Professional and Vocational Education], 11(1), 33-47.

Krippendorff, K. H. (2012). Content analysis: An introduction to its methodology (3rd ed.). London: SAGE Publications, Inc.

Krippendorff, K. H. (2013). Content analysis: An introduction to its methodology (3rd ed.). Thousand Oaks: Sage.

Lave, J., \& Wenger, E. (1991). Situated learning: Legitimate peripheral participation. Cambridge: Cambridge University Press.

Martin, J. (2001). Profiting from multiple intelligences in the workplace. Hampshire: Gower Publishing Limited. 
Merenti-Välimäki, H-L., Nokelainen, P., \& Tirri, K. (2005). Teknisen ammattikorkeakoulun opiskelijan matemaattinen lahjakkuus itsearvioinnin ja vanhempien vaikutuksen valossa. [Polytechnic Institution of Higher Education students' mathematical giftedness] Ammattikasvatuksen aikakauskirja [Journal of Professional and Vocational Education], 7(3), 32-46.

Nokelainen, P. (2010). Mistä on ammatilliset huippuosaajat tehty? [What are vocational experts made of?] Ammattikasvatuksen aikakauskirja [Journal of Professional and Vocational Education], 12(2), 4-12.

Nokelainen, P. (2016). Modelling the characteristics of vocational excellence: A case study with Finnish WorldSkills competitors. Manuscript in preparation.

Nokelainen, P., Korpelainen, K., \& Ruohotie, P. (2009). Ammatillisen huippuosaamisen kehittymiseen vaikuttavat tekijät: Tapausesimerkkinä suomalaiset ammattitaidon maailmanmestaruuskilpailuihin osallistuvat ja valmentautuvat nuoret. [Factors Influencing Development of Vocational Excellence: A case study of Finnish WorldSkills competition competitors'] Ammattikasvatuksen aikakaus- kirja [Journal of Professional and Vocational Education], 11(2), 41-53.

Nokelainen, P., \& Ruohotie, P. (2002). Modeling Student's Motivational Profile for Learning in Vocational Higher Education. In H. Niemi, \& P. Ruohotie (Eds.), Theoretical Understandings for Learning in the Virtual University (pp. 177-206). Hämeenlinna: RCVE.

Nokelainen, P., \& Ruohotie, P. (2009). Characteristics that Typify Successful Finnish World Skills Competition Participants. Paper presented at the annual meeting of the American Educational Research Association, San Diego, USA.

Nokelainen, P., Smith, H., Rahimi, M., Stasz, C., \& James, S. (2012). What contributes to vocational excellence? Characteristics and experiences of competitors and experts in WorldSkills London 2011. Madrid: WorldSkills Foundation.

Nokelainen, P., Stasz, C., \& James, S. (2013). What contributes to vocational excellence? A pilot study of the individual characteristics of the WorldSkills UK 2011 squad. SKOPE Research Paper No. 118. Oxford: SKOPE Publications, University of Oxford.

Nokelainen, P., Tirri, K., Campbell, J. R., \& Walberg, H. (2007). Factors that Contribute or Hinder Academic Productivity: Comparing two groups of most and least successful Olympians. Educational Research and Evaluation, 13(6), 483-500.

Patton, M. (1987). How to use qualitative methods in evaluation. London: Sage.

Patton, M. (1990). Qualitative evaluation and research methods (2nd ed.). Newbury Park, CA: Sage.

Pylväs, L., Nokelainen, P., \& Roisko, H. (2015). Investigation of the role of natural abilities, self-regulative abilities and environmental conditions to Finnish air traffic controllers' vocational development. Journal of Workplace Learning, 27(3), 241-263. 
Ruohotie, P., Nokelainen, P., \& Korpelainen, K. (2008). Ammatillisen huippuosaamisen mallintaminen: Teoreettiset lähtökohdat ja mittausmalli [Modeling of Vocational Excellence: Theoretical framework and measurement model]. Ammattikasvatuksen aikakauskirja [Journal of Professional and Vocational Education], 10(1), 4-16.

Saarinen, H. (2010). Ammattitaito-valmennus - kohti huippu-osaamista [Vocational skills training - towards vocational excellence]. Ammattikasvatuksen aikakaus-kirja [Journal of Professional and Vocational Education], 12(2), 20-25.

Schreier, M. (2014). Qualitative content analyses. In U. Flick (Ed.), The Sage handbook of qualitative data analysis (pp. 170-183). London: Sage.

Schunk, D. H., \& Ertmer, P. A. (2000). Self-regulation and academic learning. In M. Boekaerts, P. R. Pintrich, \& M. Zeidner (Eds.), Handbook of self-regulation (pp. 631-650). San Diego, CA: Academic Press.

SkillsFinland. (2017). Tietoa kilpailuista [Information about skills competitions]. Retrieved from: http://skillsfinland.fi/fi/kansainvaliset-kilpailut/tietoa-kilpailu- ista/

Tirri, K., \& Nokelainen, P. (2011). Measuring multiple intelligences and moral sensitivities in education. Rotterdam: Sense Publishers. 138 pages.

Tuomi-Gröhn, T., Engeström, Y., \& Young, M. (2003). From transfer to boundarycrossing between school and work as a tool for developing vocational education: An introduction. In T. Tuomi-Gröhn, \& Y. Engeström (Eds.), Between school and work: New perspectives on transfer and boundary-crossing (pp. 1-19). Amsterdam: Pergamon Press.

Virtanen, A., \& Tynjälä, P. (2008). Students' experiences of workplace learning in Finnish VET. European Journal of Vocational Training, 44(2), 200-213.

Virtanen, A., Tynjälä, P., \& Eteläpelto, A. (2014). Factors promoting vocational students' learning at work: Study on student experiences. Journal of Education and Work, 27(1), 43-70.

Weiner, B. (1974). Achievement motivation and attribution theory. Morristown, NJ: General Learning Press.

Wilde, S., \& James Relly, S. (2015). WorldSkills UK training managers: Midas touch or fool's gold? International Journal for Research in Vocational Education and Training, 2(2), 85-98.

WSI. (2010). WorldSkills International: History 1950-2010. Madrid: WorldSkills International.

Zimmerman, B. J. (1989). A social cognitive view of self-regulated academic learning. Journal of Educational Psychology, 81(3), 329-339.

Zimmerman, B. J. (1998). Developing self-fulfilling cycles of academic regulation: An analysis of exemplary instructional models. In D. H. Schunk, \& B. J. Zimmerman (Eds.), Self-regulated learning: From teaching to self-reflective practice (pp. 1-19). New York, NY: The Guilford Press.

Zimmerman, B. J. (2000). Attaining self-regulation. A social cognitive perspective. In M. Boekaerts, P. R. Pintrich, \& M. Zeidner (Eds.), Handbook of self-regulation (pp. 13-39). San Diego, CA: Academic Press.

Zimmerman, B. J. (2006). Development and Adaptation of Expertise: The Role of SelfRegulatory Processes and Beliefs. In K. A. Ericsson, N. Charness, P. J. Feltovich, \& 
R. R. Hoffman (Eds.), The Cambridge Handbook of Expertise and Expert Performance (pp. 705-722). Cambridge: Cambridge University Press.

Zimmerman, B. J., \& Kitsantas, A. (1997). Developmental phases in self-regulation: Shifting from process to outcome goals. Journal of Educational Psychology, 89(1), 29-36.

Zimmerman, B. J., \& Kitsantas, A. (2005). The hidden dimension of personal competence: Self-regulated learning and practice. In A. J. Elliot, \& C. S. Dweck (Eds.), Handbook of competence and motivation (pp. 509-526). New York: The Guilford Press. 


\section{Bibliographical Note}

Laura Pylväs is a $\mathrm{PhD}$ student at the Faculty of Education at the University of Tampere, Finland. Her research interests focus on professional and vocational expertise and excellence, workplace learning and intercultural competence.

Dr Petri Nokelainen is a Professor of Engineering Pedagogy in the Tampere University of Technology, Finland. His research interests include investigation of professional growth and learning, exceptional abilities (professional and vocational excellence), quantitative methods and psychometrics (Bayesian statistics, survey development), and technologyenhanced learning (pedagogical usability).

\section{Acknowledgement}

This research was supported by a research grant from Academy of Finland. 